\title{
METAFISIKA MEDIASI TEKNOLOGIS: KRITIK ATAS FILSAFAT TEKNOLOGI KLASIK
}

\section{Imam Wahyudi}

Fakultas Filsafat, Universitas Gadjah Mada

\section{Rangga Kala Mahaswa}

Ze-No: Centre for Logic and Metaphysics

Email: rangga.mahaswa@gmail.com

\section{Abstrak}

Penelitian ini menjelaskan posisi filosofis dan kritik terhadap pandangan filsafat teknologi 'klasik' yang cenderung terjebak pada persoalan distingsi antara subjek dan objek serta pesimisme-romantisme terhadap eksistensi teknologi. Tujuan utama penelitian ini untuk memberikan pemahaman komprehensif melalui beberapa pendekatan filsafat teknologi kontemporer tentang corak-corak mediasi teknologi. Penelitian ini merupakan analisis historis faktual dengan menggunakan studi kepustakaan serta telaah refleksi filosofis. Temuan utama penelitian ini ialah memetakan pandangan yang membangun orientasi metafisika mediasi teknologis dengan melibatkan beberapa pendekatan. Pertama, Posfenomenologi memandang mediasi teknologis secara relasional dan intensional daripada distingsi subjek-objek. Kedua, Teori Jaringan Aktor pada pendekatan simetris antara manusia dan non-manusia. Ketiga, Simondon dan Harman menganalisis ontologis alat dan teknologi yang selalu berelasi dengan manusia. Terakhir, sudut pandang teori kritis membaca relasi teknologi tidak hanya netralinstrumental namun memiliki daya transformatif serta emansipatoris. Pendekatan mediasi teknologis dapat menjadi subjek pembahasan baru metafisika teknologi dalam mengatasi limitasi filsafat teknologi klasik.

Kata-kata kunci: Mediasi teknologis, Posfenomenologi, Relasi, Subjek-Objek, Teknologi

\section{Abstract}

This paper aims to propose philosophical criticism toward 'classical' thinking on philosophy of technology. This set of thinking tends to be 
trapped in the distinction between subject-object and romantic-pessimisms on the existence of technological dominance. The authors objective is to provide comprehensive understanding through contemporary approaches in philosophy concerning technological mediation. The study employs factual historical analysis and philosophical reflection to understand technological mediation patterns. The result maps point of view that develops a metaphysical orientation of technological mediation in terms of several approaches. Postphenomenological approaches technological mediation in a relational and intentional context rather than providing a subject-object distinction. Actor-network theory improves the asymmetrical relation of humans and non-humans. Simondon and Harman provide for ontological analysis of tools and technology in human relationships. Critical theory of technology opens the chance that technological relations are not only neutral-instrumental but have transformative and emancipatory power. Therefore, the technological mediation approach can become a new subject in the metaphysics of technology discourse in overcoming the limitations of the classical philosophy of technology.

Keywords: Postphenomenology, Subjects-Objects, Tools-Being, Mediation, Technological Mediation.

\section{PENDAHULUAN}

Sejarah filsafat teknologi tidak dapat dilepaskan dari perdebatan antara tokoh atau mazhab pemikiran tertentu. Filsafat teknologi sebelum tahun 1980an, masih berorientasi atas kritik kondisi sosial masyarakat teknologis. Hal tersebut sangat dipengaruhi oleh adanya arus dominan pandangan eksistensialisme yang kemudian cenderung pesimis terkait munculnya dominasi teknologi atau justru sebaliknya bersikap romantisme tentang ide teknologi yang ideal (Brey, 2010).

Orientasi pemikiran filsafat teknologi klasik cenderung khas dalam melihat teknologi semacam 'monster' yang siap melahap dimensi-dimensi kemanusiaan. Teknologi sebagai sesuatu hal yang menakutkan, mengancam, dan bahkan merusak tatanan masyarakat. Teknologi dianggap merusak nilai-nilai spiritual serta 
berorientasi pada ekonomi kapitalistik. Oleh karena itu, para pemikir awal tersebut cenderung merindukan konsepsi masyarakat yang harmonis dan tidak terkontrol oleh ciptaannya sendiri.

Penelitian lanjutan perlu untuk merespon pandangan distopia teknologi salah satunya melalui kerangka metafisik. Secara umum, pokok bahasan penelitian ini akan menjelaskan secara komprehensif alasan di balik keterpisahan antara manusia (subjek), teknologi (objek), dan dunia (objek) yang melatarbelakangi pemikiran filsafat teknologi klasik. Asumsi dasar penulis melihat demarkasi ini membawa konsekuensi logis terhadap pandanganpandangan yang cenderung pesimistik sekaligus romantisme terhadap teknologi (Achterhuis, 2001). Misalnya, persoalan determinisme teknologi, persoalan status nilai teknologi, atau pun persoalan yang hanya menempatkan pada satu aspek saja, hanya bertitik tolak pada subjek semata ataupun objek teknologi di satu sisi (Franssen et al., 2016). Oleh karena itu, perlu adanya pembahasan secara komprehensif untuk mengkritik kekurangan pandangan filsafat teknologi 'klasik' tersebut.

Tulisan ini juga bertujuan untuk menilik kembali sejarah demarkasi subjek-objek dalam filsafat teknologi sehingga dapat memetakan persoalan tersebut sekaligus meneliti status mediasi teknologi sebagai landasan metafisiknya. Argumentasi yang dibangun melalui pijakan proyek Posfenomenologi (Ihde, 2009), yang menjelaskan empat jenis relasi teknologis. Ruang eksplanasi filosofis tersebut membuka kemungkinan pemahaman ulang tentang keterpisahan subjek-objek yang diperkuat dengan pandangan mediasi oleh Peter Paul Verbeek. Mediasi merupakan konsep yang berbeda secara implisit dengan relasi. Apabila relasi membahas persoalan melalui subjek yang terarah pada objek maupun sebaliknya, konsep mediasi melihat bahwa teknologi yangtermediasi itulah yang dapat menjelaskan status metafisik subjek dan objek pada diskursus teknologi (Rosenberger \& Verbeek, 2015).

Terakhir, penelitian ini bertujuan melakukan penelusuran beberapa gagasan filosofis teknologi yang relevan untuk membangun konsepsi tentang mediasi teknologis. Landasan ini 
diperkuat dengan menyertakan beberapa subjek pemikiran filsafat teknologi, antara lain: gagasan mediasi-persepsi posfenomenologi, Harman Graham (filsafat orientasi-objek) (Harman, 2010), Bruno Latour (teori jaringan aktor) (Latour, 2005), Gilbert Simondon (Boever, 2012; Chabot, 2013), dan Andrew Feenberg (Feenberg, 2002, 2012). Sehingga, arah penelitian ini tidak hanya sekedar menelusuri diskursus subjek-objek sepanjang historisitas filsafat teknologi tetapi juga menginventarisasi serta mengidentifikasi corak-corak mediasi pada perkembangan filsafat teknologi lebih lanjut.

\section{PEMBAHASAN}

\section{Relasi dan Mediasi Teknologis}

Secara umum, relasi berarti hubungan, perhubungan, atau pertalian. Istilah relasi di dalam matematika justru memiliki arti yang lebih spesifik yaitu aturan-aturan yang menghubungkan dua himpunan yang berbeda. Relasi memiliki model pemetaan secara matematis yang sering disebut sebagai fungsi dari sebuah pemetaan himpunan. Artinya, apabila ada pemetaan dari himpunan A ke himpunan B maka ada relasi di mana anggota himpunan A dipasangkan dengan tepat satu anggota himpunan B. Oleh karena itu, relasi dalam konsep matematis selalu menjelaskan suatu 'sifat dari' sesuatu yang terhubung dengan yang lainnya (Negoro \& Harahap, 2010).

Berbeda dengan konsep matematis, perdebatan filosofis akan relasi jauh lebih mengarah pada perdebatan ontologis dan epistemologis. Perdebatan filosofis tentang apa itu relasi mendasari pertanyaan seputar identitas, properti, hubungan, bahkan keadaan suatu objek maupun antara objek-objek lain (MacBride, 2016). Konsepsi tentang relasi lantas dapat ditarik pada dimensi mediasi teknologis untuk menjembatani hubungan di antara manusia, teknologi, dan dunia. Mediasi memungkinkan menjelaskan hubungan identitas atau properti dari suatu objek ke objek lainnya dengan suatu kondisi yang berbeda. 
Menariknya, pembahasan relasi pada teknologi telah mendapat perhatian lebih dari para pemikir posfenomenologi. Posfenomenologi memperkenalkan ontologi relasional. Istilah ini merujuk pada penjelasan bahwa relasi yang muncul bukan lagi diartikan sebagai relasi yang abstrak, relasi terhadap 'diri-nya' sendiri atau bahkan relasi yang transendental. Rosenberger dan Verbeek (2015) menjelaskan pemahaman relasi teknologi yaitu ketika teknologi mampu untuk membangun relasi di antara penggunanya dan dunianya, misalnya, saat sonografi membentuk pengalaman dan ekspektasi ibu yang sedang hamil terhadap kondisi kandungannya. Teknologi juga membantu membentuk 'subjektivitas' dari penggunanya dan 'objektivitas' dunianya.

Relasi dalam konteks posfenomenologi membantu pemahaman bahwa teknologi menjadi bagian penting untuk memahami cara kerja 'ontologi relasional'. Adapun beberapa contoh sederhana ketika teknologi, manusia, dan dunia memiliki relasi secara ontologis yang dapat membangun subjektivitas sekaligus objektivitas tertentu. Adanya teleskop mengonstitusikan penggunanya sebagai 'observer' dan langit sebagai realitas yang observable bagi pengamatnya. Tidak berbeda jauh dengan relasi teleskop dengan dunia, sonografi mampu memberikan gambar realitas terhadap janin di dalam kandungan ibu hamil sehingga orang tua bertanggung jawab dengan kondisi kesehatan anaknya. Subjek dan objek bukan sebagai entitas yang pre-given, artinya bukan sebagai suatu entitas yang ada terberi secara terpisah, melainkan justru dikonstitusikan melalui relasi teknologis yang termediasi di antara keduanya (subjek-objek).

Relasi teknologis terjalin disebabkan adanya interaksi yang menghubungkan antara manusia dan teknologi, atau teknologi dan dunia. Interaksi tidak secara penuh membantu penjelasan mengenai konsep relasi teknologi secara mendalam (Verbeek, 2015a). Alasannya, interaksi hanya menjelaskan sejauh 'tindakan diantara', sehingga mengindikasikan apa yang terjadi di antara manusia dan artefak teknologi ataupun sebaliknya. Konsep interaksi justru akan membawa konsekuensi pemahaman klasik 
yang memungkinkan adanya keterpisahan antara subjek-manusia dan objek-teknologi, 'di-antara' menjadi suatu tindakan yang spesifik. Konsep interaksi tidak hanya berhenti ketika telah mampu membaca suatu 'aksi di-antara' melainkan harus bergerak lebih lanjut lagi yaitu melalui pendekatan mediasi (Verbeek, 2015b).

Basis pendekatan mediasi justru membalikkan pemahaman umum tentang relasi antara manusia dan teknologi. Interaksi muncul karena adanya mediasi yang mendasarinya. Mediasi bukan sebagai action in-between melainkan justru menjadi 'konfigurasi dasar', keduanya subjek dan objek hadir dan dikonstitusikan melalui relasi keduanya. Mediasi lalu menjadi the origin of entities (asal-usul entitas), dari pada hanya sekedar berada di-antara kedua relasi tersebut. Posfenomenologi menjelaskan konsep mediasi dengan menempatkan subjektivitas manusia dan objektivias dunianya sebagai hasil dari mediasi-mediasi. Mediasi teknologi tidak semata-semata hanya sebagai 'perantara' yang 'menyampaikan' aspek spesifik dari dunia objektif ke pikiran subjek; 'mereka' adalah mediator yang membantu membentuk apa yang nyata bagi manusia, dan apa yang manusia miliki terkait dengan realitas itu (Verbeek, 2012).

Graham Harman sebagaimana dikutip oleh Verbeek (Verbeek, 2012) ketika membaca gagasan Heidegger, mengatakan bahwa 'mediasi teknologis bukanlah mediasi-sesuatu, atau antara-sesuatu, tetapi kondisi ontologis dari semua hal'. Pada satu sisi, pendekatan posfenomenologi menitikberatkan pada pandangan bahwa manusia dan dunianya ialah produk dari mediasi dan keduanya bukan sebagai titik awal relasi di-antara, artinya mediasi mendahului relasi teknologi. Teknologi tidak hanya sekedar menjadi perantara atau di antara manusia dan dunianyapemahaman tradisional, melainkan sebagai hasil dari konfigurasi, di mana teknologi bergabung dengan konteks relasi manusia dengan dunianya (Verbeek, 2012). Ketika manusia menambahkan atau mengimplan bagian tubuhnya 'cyborg' maka saat itulah lahir tindakan dan pengalaman yang berbeda. Begitu juga ketika ada orang yang mengalami kesulitan pendengaran lalu mendapatkan 
alat bantu dengar bukan berarti teknologi tersebut mengembalikan pendengaran manusia secara penuh melainkan hanya mengonfigurasi aktivitas keduanya, manusia dan dunia. Tidak hanya teknologi yang terintegrasi dengan manusia, pengembangan teknologi mutakhir seperti smart-city atau smart-environments yang menandai bahwa interaksi antara manusia dengan teknologi meruntuhkan pemahaman tradisional yang melihat teknologi hanya sebatas kebergunaan tanpa memahami kejelasan konteks tertentu.

Dari penjelasan di atas, perspektif pendekatan mediasi di filsafat teknologi, menandai bahwa hubungan antara manusia dan teknologi bukan lagi sekedar interaksi 'satu arah' melainkan keduanya adalah hasil dari interaksi tersebut. Keduanya bukan sebagai entitas 'pre-given' melainkan hadir secara bersamaan membentuk satu dengan yang lainnya. Selain itu, di berbagai macam kasus relasi teknologis tidak hanya sekedar relasi satu arah atau sebatas individu semata, namun justru lebih dari sekedar relasi yang membentuk antara manusia dan dunianya, relasi yang lebih luas, di mana teknologi memainkan peran mediasi. Lantas, apa yang didesain bukan hanya benda-teknologi tetapi relasi manusia dan dunia yang membentuk praktik dan pengalamannya. Mendesain teknologi oleh karenanya tidak hanya sekedar membuat sesuatu menjadi berguna, melainkan juga mendesain manusia itu sendiri pada konteks interaksi yang spesifik. Segala teknologi yang dikembangkan akan membuat beragam relasi antara penggunanya dan dunia-nya, dan berkonsekuensi pada tindakan sekaligus pengalaman.

Uniknya, Verbeek (2005) mengartikan interaksi antara manusia dan artefak teknologi tidak dalam term fungsi dan kegunaan, melainkan karakteristik sebagai immersion (imersi atau menyerap/melibatkan) dan fusion (fusi atau penggabungan). Hal itu disebabkan karena memahami teknologi hanya berlandaskan fungsi dan kegunaannya saja dapat membawa konsekuensi atas reduksionis atau simplifikasi peranan teknologi. Manusia dalam kesehariannya memiliki tujuan dan intensionalitas terhadap 
sesuatu hal yang secara nyata tidak dapat terlepas dari teknologi yang mereka gunakan secara mandiri. Media sosial misalnya telah membangun bentuk dan dimensi relasi sosial baru yang sebelumnya tidak pernah terlintas dalam benak perancang 'media sosial'. Teknologi seolah melampaui fungsinya tetapi justru mampu membantu membentuk 'eksistensi' sosial yang lain. Teknologi oleh karena itu menjadi sangat kompleks sekaligus rumit dari pada sekedar kegunaannya atau fungsinya. Teknologi dapat dilihat sebagai (i) ekstensi atau extention, (ii) dialektika atau dialectics antara manusia dan teknologi, dan (iii) relasi manusia-teknologi dalam kaitan campuran atau hybrids (Verbeek, 2015a).

Pertama, Extension. Ketika mendekatkan relasi manusiateknologi secara ekstensional, teknologi muncul sebagai alat atau instrumen. Teknologi memungkinkan manusia untuk melakukan sesuatu secara spesifik. Pandangan ini menjadikan teknologi dilihat secara netral. Sebagai ekstensi, teknologi hanya memfasilitasi tindakan dan pengalaman manusia daripada secara aktif membantu membentuk mereka. Pada konteks ini, tindakan manusia dengan teknologi memiliki ruang tanggung jawab terkait persoalan moral. Misalnya, ketika orang mengendarai mobil terlalu kencang atau membunuh dengan pistol, maka teknologi transportasi maupun senjata tidak dapat disalahkan, justru karena ekstensi tersebut manusia bertanggung jawab atas tindakannya.

Kedua, Dialectics. Pendekatan lain untuk hubungan manusiateknologi memiliki sifat dialektis, artinya bahwa teknologi memungkinkan membuka sifat pertentangan daripada kontinuitas antara keduanya. Teknologi di satu sisi memiliki kekuatan yang signifikan untuk mengubah, melampaui, atau memaksa manusia menjadi teralienasi. Misalnya, kajian Marxist tentang para buruh yang teralienasi dari proses produksi dan produksinya sendiri atau kritik terkini tentang informasi teknologi yang berdampak pada kemampuan kognitif. Versi lain dari pendekatan dialektik ialah bahwa teknologi sebagai eksternalisasi dari aspek spesifik manusia, yang memungkinkan manusia berkembang. Gagasan paling terkenal pernah dilontarkan oleh Ernst Kapp yang memandang 
bahwa teknologi sebagai proyeksi dari organ manusia. Misalnya, palu sebagai proyeksi dari kepalan tangan atau di zaman sekarang komputer sebagai proyeksi sistem komputasi manusia (Kapp, 2018). Pengembangan relasi dialektis ini tidak hanya sekedar berhenti pada teknologi sederhana melainkan juga pada teknologi yang lebih mutakhir yang membuka lebih lanjut interaksi secara fisik dan kognitif antara manusia dan mesin atau bahkan mesin otomatis.

Ketiga, Hybridity. Pendekatan ini berusaha untuk menjelaskan persoalan mendasar di antara pendekatan instrumental dan dialektis, ataupun pendekatan secara ekstensi dan oposisi yang hanya menempatkan teknologi dalam dua di sisi, satu sisi sebagai subjek manusia dan sisi lain sebagai objek teknologis. Konsekuensinya, pemisahan ini gagal memahami rumitnya jejaring antara manusia dan teknologi. Untuk dapat memahami persoalan ini lebih lanjut diperlukan pendekatan khusus yang dikenal sebagai istilah hybrids, yang mendekatkan pada pengertian bahwa teknologi dan manusia membantu untuk membentuk satu dengan lainnya. Teknologi sebagai elemen dan bagian dari eksistensi manusia. Teknologi instrumental misalnya teleskop membantu ilmuwan untuk melihat bintang-bintang secara lebih detail. Tidak hanya membantu manusia dalam memahami dunianya tetapi juga mampu memberikan kualitas dari interaksi sosial dan relasi-relasi yang termediasi oleh karena teknologi maupun struktur sosialnya.

Teori mediasi teknologis memberikan pandangan yang lebih mendalam dalam proses manusia membentuk dirinya sebagai manusia begitu juga teknologi yang ada. Teknologi berkembang secara lebih matang dan mendalam terutama pada pembentukan desain maupun pertimbangan dimensi moral etisnya. Hampir seluruh teknologi yang ada di dunia ini berkembang karena berbagai pertimbangan, tidak hanya sekedar sebagai produk jadi, alat, maupun instrumen yang membantu manusia, tetapi juga memiliki beragam dimensi yang saling terkait dengan manusia. Mendesain teknologi artinya mendesain manusia secara bersamaan. Situasi ini dapat dipahami lebih mendalam dari teori 
Posfenomenologi Don Ihde yang membaginya ke dalam empat susunan teori mediasi (relasi teknologi-manusia-dunia).

Menurut Verbeek (2015b), teori mediasi bertujuan untuk menginvestigasi struktur mediasi teknologis yang terbagi ke dalam tiga tipe kategori. Pertama, pembahasan relasi antara manusia, teknologi, dan dunianya. Kedua, identifikasi berbagai macam aplikasi dari proses desain sampai pengaruhnya pada manusia. Ketiga, beberapa model pengaruh teknologi terhadap tindakan manusia atau proses pengambilan keputusan.

Berpijak pada pembacaan mediasi secara teknologis menurut Verbeek, penulis kemudian mengelaborasi lebih lanjut dalam konteks untuk memahami lebih dalam filsafat teknologi maupun eksistensi teknologi di antara manusia dan teknologi. Elaborasi yang dilakukan adalah dengan mencari alasan mengapa Verbeek membawa persoalan mediasi di belantara filsafat teknologi. Adapun alasan filosofis yang dibangun yaitu untuk menghindari simplifikasi pandangan terhadap hubungan antara manusia dan dunia termasuk teknologi yang ada di dalamnya, yang sejatinya sangat rumit. Kompleksitas inilah yang kemudian dapat dipertahankan sebagai dasar untuk mengkritik pandangan filsafat teknologi klasik yang terjebak pada pesimisme, romantisme, dan spekulatif.

\section{Kritik Filsafat Teknologi Klasik}

Secara historis, filsafat teknologi memiliki dua fase yakni fase filsafat teknologi klasik dan fase teknologi kontemporer. Pembagian ini didasarkan pada pembedaan titik analisisnya. Filsafat teknologi kontemporer lahir sejak tahun 1980an ketika munculnya kajian interdisipliner antara ilmu dan teknologi serta filsafat. Pada dekade itu, istilah tekno-sains semakin populer berkat adanya kajian Science and Technology Studies (STS) dan mengubah paradigma baru pada sistem analisis filsafat teknologi (Brey, 2010).

Akar pemisahan ini bermula dari kritik empirical turn (Achterhuis, 2001) atas keterbatasan filsafat teknologi klasik dalam menganalisis struktur teknologi. Kesalahannya ialah memaksakan 
penalaran filosofis tertentu untuk memahami teknologi sehingga menyebabkan bias dan ambiguitas terhadap relasi teknologi dan manusia. Misalnya pemaksaan pembacaan tokoh tertentu terhadap teknologi secara umum. Padahal, teknologi secara riil tidak dapat dijelaskan hanya dengan memaksakan suatu pemahaman filosofis tertentu. Sekalipun, secara model berpikir filsafat adalah dibenarkan, namun pembacaan secara parsial tetapi dengan hasil spekulasi final akan menutup kemungkinan memahami teknologi secara lebih luas, mendalam, dan bersifat progresif.

Persoalan spekulatif yang berlebihan muncul di era awal filsafat teknologi klasik yang membawa pengulangan pemikiran tetapi tidak pernah selesai sampai pada akar persoalan. Pandangan Marcuse misalnya Manusia Satu Dimensi mungkin secara kritik tepat karena membawa 'kesadaran' akan situasi kondisi teknologi yang mendominasi, namun di satu sisi justru menolak persoalan yang lebih konkret tentang realitas parsial teknologi. Pada Tabel 1 terdapat gambaran orientasi kedua pandangan filsafat teknologi klasik dan kontemporer.

Menurut Brey (2010) filsafat kontemporer lahir akhir abad ke20, yang bertujuan mengkritisi pemikiran tentang teknologi sekaligus mencoba merekonstruksi dan mentransformasi bidang filsafat teknologi. Beberapa alasan yang mendasari perlunya adanya perubahan antara lain: Pertama, filsuf teknologi klasik hanya membawa narasi tunggal; narasi pesimis atau destruktif tentang teknologi. Teknologi dipandang sebagai pusat kesadaran kolektif bersamaan dengan situasi yang lebih ambivalensi antara juru selamat sekaligus penghancur.

Kedua, filsafat teknologi klasik cenderung membawakan wacana dan imaji teknologi sebagai sesuatu hal yang tak terhentikan dan otonom. Pandangan ini membawa konsekuensi logis bahwa manusia menjadi kehilangan kendali atas teknologinya sendiri. Untuk mengatasi pandangan teknologi yang independen, maka pada tahun 1980an muncul paradigma keilmuan baru yang dikenal dengan istilah Studi Ilmu dan Teknologi atau Science and Technology Studies (STS). Paradigma STS termasuk bagian dari 
pandangan yang menekankan pada kontingensi dan konstruksi sosial dari teknologi, kemungkinan desain, pembuatan, dan penggunaan teknologi secara berbeda-beda sesuai dengan kondisi luaran sosialnya (Simondon, 2003). Pada posisi ini, teknologi ditarik ke ranah sosial sehingga mematahkan tesis teknologi yang independen dan bebas.

Tabel 1. Perbedaan Filsafat Teknologi Klasik \& Filsafat Teknologi Kontemporer (Mahaswa, 2018)

\begin{tabular}{|l|l|}
\hline Filsafat Teknologi Klasik & Filsafat Teknologi Kontemporer \\
\hline Deterministik / Dominasi & Penundaan / 'Netral' \\
\hline Negatif / Pesimis & Ambivalensi \\
\hline Umum & Spesifik \\
\hline Abstrak & Konkret - Pragmatis \\
\hline Spekulatif - Reflektif & Deskriptif - Analitik \\
\hline
\end{tabular}

Ketiga, kritik terhadap filsafat teknologi awal yang berpandangan sangat umum dan abstrak karena melihat teknologi dengan T-kapital. Gagasan ini membawa konsekuensi yang cukup ironis sebab menjustifikasi teknologi secara umum dan tidak lagi membedakan tiap-tiap teknologi yang hadir di tengah-tengah masyarakat. Generalisasi pandangan ini tidak hanya berpusat secara filosofis tetapi juga meluas baik secara konseptual, konkret, praktis, status artefak atau proses teknologi. Teknologi sering kali hanya diterjemahkan secara umum atau 'negatif' tanpa menyentuh isu yang sangat spesifik dari teknologi. Dengan demikian, pandangan ini hanya akan membawa konsekuensi bahwa ciri khas teknologi yang bebas dan negatif akan mengalami kesulitan jika harus menjadi analisis teknologi di masa depan.

Tren ini membawa banyak transisi pemikiran (1980-1990) yang mengarahkan banyak pemikir saat membangun beragam varian metode filsafat yang lebih mutakhir misalnya muncul NeoHeideggerian, Neo-Teori Kritis, Neo-Marxisme, dan bahkan 
Posfenomenologi yang membawa perubahan berarti pada tubuh filsafat teknologi kontemporer. Selain varian metode analisis, beberapa tradisi lain menjadi pendekatan baru filsafat teknologi seperti pragmatisme (Larry Hickman), postrukturalisme (Donna Haraway), posfenomenologi (Don Ihde), demokratisasi teknologi (Andrew Feenberg), atau STS (Bruno Latour). Mereka memiliki fokus kajian terhadap bentuk praksis teknologi dalam keseharian mulai dari kajian media, budaya, politik, serta studi lainnya yang relevan sehingga dapat menarik persoalan teknologi sebagai sebuah pembahasan yang konstruktif.

Berikut hasil analisis penulis akan corak mediasi teknologis terhadap transisi awal filsafat teknologi klasik yang terbagi menjadi tiga tipe yaitu deterministik, dominasi dan netralitas. Pandangan filsafat teknologi klasik membawa konsepsi mediasi teknologi pada batasan-batasan antara dominasi kekuasaan subjek atau dominasi determinasi objek dan rasionalitas teknologis. Pandangan ini memberikan konsekuensi relasional teknologi dan manusia sebagai entitas yang saling terpisah. Keduanya sama-sama memiliki kuasa yang saling mendominasi satu sama lain. Oleh karena itu, terdapat keterpisahan ontologis bahwa manusia sebagai subjek yang independen, teknologi sebagai material objek, dan alam sebagai pendukung. Jurang pemisahan ontologis terkait relasi teknologi dapat dijelaskan menjadi tiga tipe atau model yang berbeda.

\section{Tipe I “Deterministik" $: \mathrm{M} \leftarrow \mathrm{T} \rightarrow \mathrm{A}$}

Berdasarkan pada tipe I maka pemisahan secara ontologis entitas ketiganya merupakan hal yang niscaya sebab berdasarkan asumsi epistemik teknologi di mana objek merupakan inti dari persoalan filosofis yang harus diselesaikan. Umumnya, mereka membawa pandangan objek teknologi sebagai entitas yang berdiri sendiri dengan dominasi kekuasaan tertentu. Corak pandangan ini penulis sebut sebagai konsep mediasi determinisme. Mengapa mediasi ini bercorak deterministik? Asumsi filosofisnya membawa konsepsi tentang teknologi yang dibawa oleh tradisi pemikiran Karl 
Jaspers dalam (Verbeek, 2006), Herbert Marcuse dalam (Vieta, 2010), dan Jacques Ellul dalam (Zwier et al., 2016). Teknologi dianggap sebagai sesuatu hal material yang mempengaruhi dan bahkan mendominasi keberadaan sosial masyarakat manusia sekaligus mampu mengeksploitasi alam secara besar-besaran.

Pandangan Heidegger (Heidegger, 1977; Thomson, 2000) tentang 'pembingkaian' melahirkan pandangan yang cukup pesimistik di kalangan pemikir teknologi pasca-Heideggerian karena mengandaikan adanya arah gerak yang selalu membingkai realitas. Jika dipahami secara sempit, artinya teknologi selalu mendominasi ruang gerak alam terlebih lagi manusia. Teknologi menjadi bagian inti dari kehidupan kesehariannya. Karl Jaspers membawa pandangan bahwa teknologi sebagaimana 'iblis' yang membawa kehancuran. Unsur non-material manusia terdegradasi termasuk kreativitas atau spiritualitasnya karena adanya dominasi teknologi modern.

Masih dengan satu garis persoalan yang sama, dominasi teknik menjalar hingga ke seluruh aspek kehidupan masyarakat. Ellul menyebutnya sebagai masyarakat teknologis. Masyarakat yang telah didominasi oleh teknik. Marcuse menyatakan bahwa teknologi sebagai objek material tunggal mampu mengarahkan tindakan manusia berdasar pada rasionalitas teknologis. Alam bukan lagi pokok bahasan Marcuse, karena asumsi filosofisnya, apabila manusia sudah terbuai dengan rasionalitas teknologis yang serba kaku tanpa improvisasi, maka alam hanya akan menjadi objek pemuas keserakahan manusia. Alam menjadi objek eksploitasi.

$$
\text { Tipe II “Dominasi” : } \mathrm{M} \rightarrow(\mathrm{T}-\mathrm{A})
$$

Hampir menyerupai pandangan sebelumnya, pada bagian ini (Tipe II), baik Alam maupun Teknologi dianggap sebagai objek pemuas dari pada subjek manusia. Pandangan dominasi kapitalistik ini merupakan inti kritik dari sudut pandang mazhab Frankfurt generasi pertama. Ketika nalar teknologi tidak lagi ada pada teknologi itu sendiri melainkan sudah melekat pada subjek 
sebagai manusia dengan segala daya usahanya. Teknologi menjadi entitas kes ekian kalinya. Pandangan yang lebih mengarahkan pada pertahanan eksistensi manusia yang bersifat serakah dan rakus akan sumber daya (alam maupun manusia) untuk dapat mengembangkan teknologi yang dominan. Penguasaan teknologi digunakan sebagai alat untuk mendominasi seluruh aspek kemanusiaan maupun alam yang ada. Hanya kelompok tertentu yang memanfaatkan teknologi ini. Pandangan ini memang sangat terkesan 'kritis' karena berani menarik mundur asumsi umum tentang mediasi teknologis menjadi mediasi kuasa-dominasipolitis. Namun, memiliki kelemahan yang sangat bercirikan pesimis dan pandangan akan masa depan teknologi yang distopia.

Posisi ini tidak memberikan dampak apapun terkait konsep mediasi teknologis. Status teknologis hanya sebagai medium untuk mengantarkan kuasa manusia yang mendominasi terhadap sesamanya atau alam. Artinya, teknologi menjadi benda yang sangat pasif dan sekaligus objek material bagi manusia. Teknologi hanya membawa pesan-pesan kekuasaan absolut dari kelas manusia tertentu sebagai sarana untuk menguasai sesamanya. Pandangan ini sangat tepat untuk menggambarkan bagaimana masyarakat satu dimensi ala Marcusean atau masyarakat yang fasis-totalitarian yang sangat mengandalkan kuasa teknologi yang sifatnya mengancam.

\section{Tipe III “Netralitas" : M - T - A}

Pandangan tipe yang terakhir ini sangat jauh berbeda dengan dua tipe sebelumnya. Pandangan ini lebih menyaratkan tidak adanya mediasi apapun atas eksistensi teknologi. Teknologi sebagai objek 'netral' yang tidak memberikan konsekuensi yang signifikan. Teknologi, Alam, dan Manusia menjadi setara. Teknologi adalah netral. Semua konsekuensi baik dan buruk yang melekat dari teknologi dihapuskan. Pembahasan ini semakin menjadi ambigu ketika teknologi diasumsikan tidak memberikan pertimbangan moral apapun, hanya individu yang dijatuhkan konsekuensi dan 
tanggung jawab secara moral. Pandangan ini mewakili corak filsafat teknologi yang sangat paradoks dan ambigu. Tidak banyak filosof yang berorientasi pada netralitas teknologi tetapi lebih banyak mengarah pada sifat kebergunaan atau hanya sekedar corak instrumental teknologi-hanya sebagai alat.

Hans Jonas (2014) mengkritik netralitas teknologis melalui titik etika dan moral. Corak mediasi antara manusia dan teknologi harus diiringi dengan konsepsi atas moral sekaligus tanggung jawab manusia ketika berada pada ranah praksis yang secara langsung berinteraksi dengan alamnya. Jonas kemudian mengubah asumsi bahwa teknologi tidak dapat dipandang sebagai objek yang netral karena manusia dan teknologi telah menyiratkan tanggung jawab secara moral atas kondisi alam yang ada saat ini. Kritik Jonas belum benar-benar sempurna karena masih menyisakan dimensi 'spekulasi' sekaligus belum mengandaikan bagaimana desain awal teknologi juga memberikan dampak paling fundamental terkait persoalan moral teknologi. Jonas hanya bermain pada ranah ketika manusia menerapkan teknologi pada kehidupannya yang disertai dengan tanggung jawab moral bukan membawa bagaimana teknologi memberikan kontribusi terhadap kerangka moral dan etika yang juga secara inheren membawa nilai budaya tertentu.

\section{Pengembangan Mediasi Teknologis}

Corak mediasi teknologi tidak dapat dipisahkan dengan tingkat kesadaran penggunaan instrumen akan keberadaan alat yang sedang digunakannya. Setiap instrumen yang digunakan memiliki tingkat kesadaran yang berbeda-beda (Ihde, 1979, 2009). Teknologi dapat mewujud pada tataran kesadaran sebagaimana alat atau opacity dan di sisi lain ketidakperhatian pada alat ketika sedang digunakan secara transparan atau transparency. Relasi kebertubuhan mempunyai transparency tinggi dan opacity rendah. Sedangkan relasi alteritas/keberlainan, teknologi menjadi quasiyang-lain yang melaluinya manusia terhubung dapat menghadirkan transparency rendah dan opacity tinggi. Pada hubungan hermeneutis, ketidaksadaran akan wujud alat dapat 
mewujud dari penafsiran pada alat. Berbeda dengan relasi yang terakhir, relasi latar belakang tidak ditandai oleh transparency ataupun opacity.

Pada Tabel 2, telah terangkum berbagai jenis corak relasi antara manusia dan teknologi yang tampaknya telah mengubah persepsi manusia dari pengetahuan yang telah dan mungkin atas keterbukaan pengetahuan atau pengalaman baru. Transformasi pengalaman ini terjadi dengan latar belakang dimensi amplifikasi sekaligus reduksi. Teori instrumental dan konsep netralitas runtuh (Tipe III) ketika menggunakan pendekatan posfenomenologi sebab teknologi memberikan dua dimensi yang berbeda. Teknologi secara tidak langsung memberikan kecenderungan pada tujuan tertentu tanpa disadari (latent telic).

Tabel 2. Rangkuman Ragam Hubungan Manusia-Teknologi-Dunia (Lim, 2008: 160-161)

\begin{tabular}{|c|c|c|c|c|c|c|}
\hline $\begin{array}{c}\text { Jenis } \\
\text { hubungan }\end{array}$ & $\begin{array}{c}\text { Corak } \\
\text { hubungan }\end{array}$ & $\begin{array}{c}\text { Fokus } \\
\text { manusia }\end{array}$ & Tujuan alat & Opacity & $\begin{array}{c}\text { Transpare } \\
n c y\end{array}$ & Ciri alat \\
\hline Kebertubuhan & $\begin{array}{c}\text { (Manusia- } \\
\text { Teknologi) } \\
\rightarrow \text { Dunia }\end{array}$ & $\begin{array}{c}\text { Dunia; tugas } \\
\text { yang } \\
\text { dilakukan }\end{array}$ & $\begin{array}{c}\text { Perpanjangan } \\
\text { indera tubuh }\end{array}$ & $\begin{array}{c}\text { Sangat } \\
\text { rendah }\end{array}$ & $\begin{array}{c}\text { Sangat } \\
\text { tinggi }\end{array}$ & $\begin{array}{c}\text { Tidak } \\
\text { diperhatikan } \\
\text { dan tidak } \\
\text { disadari }\end{array}$ \\
\hline Hermeneutis & $\begin{array}{c}\text { Manusia } \rightarrow \\
\text { (Teknologi } \\
\text { - Dunia) }\end{array}$ & Alat & $\begin{array}{c}\text { Representasi } \\
\text { realitas dunia }\end{array}$ & Tinggi & Rendah & $\begin{array}{c}\text { Menumbuhkan } \\
\text { penafsiran teks } \\
\text { yang terpapar } \\
\text { pada alat. }\end{array}$ \\
\hline Keberlainan & $\begin{array}{c}\text { Manusia } \rightarrow \\
\text { Teknologi }- \\
\text { (Dunia) }\end{array}$ & $\begin{array}{c}\text { Alat } \\
\text { ataupun } \\
\text { dunia }\end{array}$ & Yang-lain & $\begin{array}{c}\text { Sangat } \\
\text { tinggi }\end{array}$ & $\begin{array}{c}\text { Sangat } \\
\text { rendah }\end{array}$ & $\begin{array}{c}\text { Alat sebagai } \\
\text { "yang-lain" }\end{array}$ \\
\hline Latar belakang & $\begin{array}{c}\text { Manusia } \rightarrow \\
\text { (Teknologi - } \\
\text { Dunia) }\end{array}$ & Dunia & Fungsional & - & & $\begin{array}{c}\text { Berfungsi di } \\
\text { latar belakang }\end{array}$ \\
\hline
\end{tabular}

Contoh sederhana Latent telic ketika penggunaan dua alat yang berbeda, yaitu pena dan komputer. Keduanya sama-sama sebagai relasi kebertubuhan (Lim, 2008). Namun kedua alat tersebut memberikan kecenderungan arah tujuan yang berbeda pada 
pengarang. Ketika menggunakan komputer akan mungkin menulis lebih cepat sedangkan menulis dengan pena akan memperlambat gerak menulis sebab dibutuhkan kehati-hatian ekstra. Kedua contoh inilah mengarahkan kepada gaya kepenulisan yang berlainan.

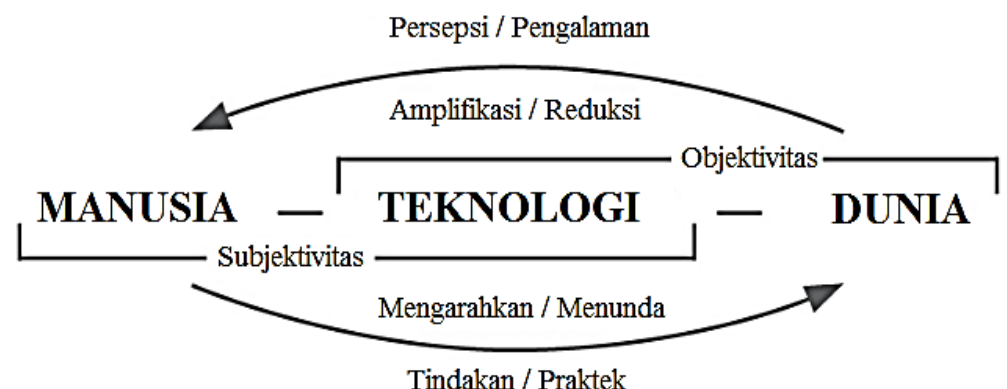

Gambar 1. Mediasi Teknologis Posfenomenologi

Teori mediasi dapat diperluas tidak hanya ketika menjelaskan relasi antara manusia dan teknologi namun juga dapat menjadi bagian penting pada taraf penggunaan di ranah desain, tanggung jawab moral, implementasi sosial dari teknologi itu sendiri (Verbeek, 2012). Mediasi teknologi sendiri sebagai respons atas gerakan netralitas karena teknologi tetap saling mempengaruhi baik dalam masyarakat maupun bentuk pengalaman manusia lainnya. Tidak hanya menjelaskan relasi teknologi secara rinci, konsep mediasi juga membantu manusia untuk mengantisipasi atau bahkan mengevaluasi teknologi serta penerapan desain teknologi di kemudian hari (Kiran \& Verbeek, 2010)

Menurut Verbeek (2008) ada dua tambahan corak relasi mediasi antara manusia dan teknologi sebagai pelengkap dari empat ragam relasi manusia-teknologi ala Ihdean. Pertama gagasan tentang cyborg dan hubungan komposit (composite) berdasarkan atas konsep intensionalitas yang kemudian mengidentifikasi tiga jenis intensionalitas antara lain: intensionalitas yang dimediasi secara 
teknologis; intensionalitas secara hibrida, dan intensionalitas komposit (Verbeek, 2008).

Pembaruan corak mediasi teknologis oleh Verbeek dilatarbelakangi karena adanya pergeseran praktik teknologi kontemporer yang lebih melibatkan penggabungan secara langsung tubuh manusia dan teknologi. Kita mengenalnya dengan istilah peningkatan kemampuan manusia atau transhumanis. Menurut Verbeek, ada momen ketika manusia dan teknologi sebenarnya tidak lagi hanya diwujudkan tetapi benar-benar bergabung menjadi satu (Verbeek, 2008: 391). Hubungan ini sering disebut sebagai relasi yang bercirikan cyborg atau hibridasi.

\section{(Manusia - Teknologi) $\leftarrow \rightarrow$ Dunia}

Relasi yang bercirikan hybrid hadir ketika teknologi secara penuh menyatu dengan manusia. Contohnya ketika manusia mengonsumsi obat-obatan atau makanan tertentu yang dapat membantu proses kesembuhannya. Selain itu, dapat juga dicontohkan ketika manusia mengalami kecelakaan kemudian pada dirinya dilekatkan organ tambahan. Subjek dan objek teknologi hadir secara tidak terpisah terutama saat berinteraksi dengan dunia.

Relasi berikutnya yaitu hubungan komposit (composite) yang didasarkan pada intensionalitas komposit sebagai "bentuk intensionalitas yang dihasilkan dari penambahan intensionalitas teknologi dan intensionalitas manusia" (Verbeek, 2008). Contoh sederhana ketika teknologi dan dunia saling tumpang tindih membentuk realitas yang lain atau realitas virtual. Dunia virtual menjadi contoh komposisi paling sempurna karena adanya 'dunia' yang lahir sebab adanya intensionalitas antara manusia dan teknologi. Hal ini berarti telah menggabungkan antara manusia dan teknologi saat terjadinya transaksi atau pertukaran antara dua arah yang berbeda secara intensif.

$$
\text { Manusia } \rightarrow \text { (Teknologi) } \leftarrow \rightarrow \text { Dunia }
$$




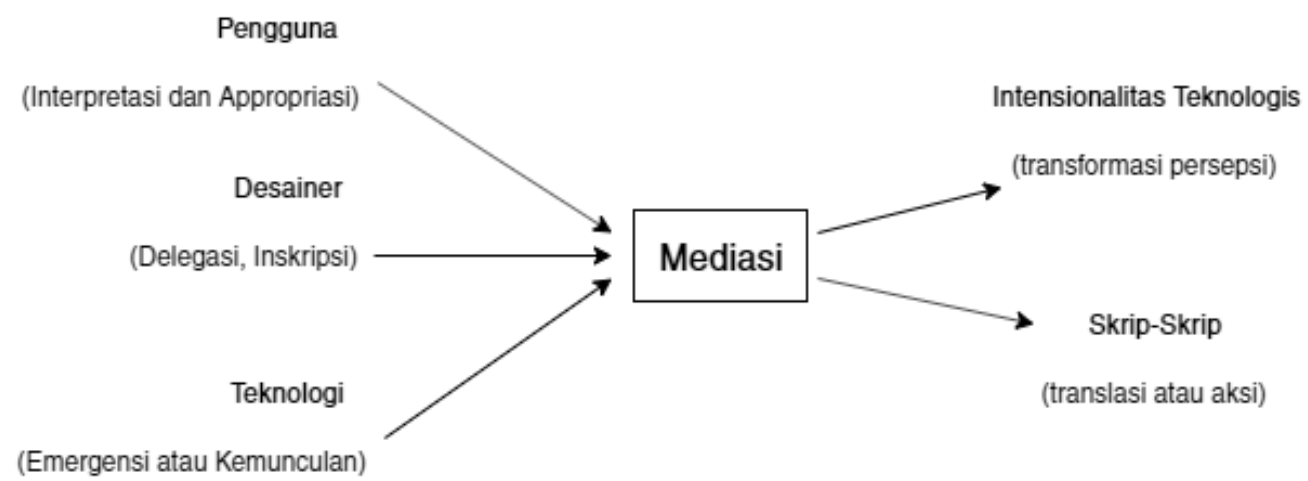

Gambar 2. Sumber Mediasi (Verbeek, 2006: 372)

Mediasi teknologi memberikan pengaruh yang cukup signifikan terhadap pengalaman hidup manusia. Beberapa kata kunci dari mediasi teknologis terbagi menjadi dua bagian yaitu pengalaman dan praksis. Struktur pengalaman merangkum mediasi teknologi secara perseptual, adanya intensionalitas teknologis, transformasi persepsi, momen amplifikasi dan reduksi (Verbeek, 2006). Sedangkan pada struktur praksis terjadinya mediasi dari tindakan, adanya skrip (script), translasi atau terjemahan dari tindakan, pengarahan (invitation) serta penundaaan (inhibition). Alasan penulis menerjemahkan bukan sebagai undangan atau penghambatan karena ranah invitation artinya mengarahkan tindakan manusia pada probabilitas realitas yang lebih terbuka sedangkan penundaan daripada istilah penghambatan karena mediasi teknologis tidak selamanya menghambat secara harfiah: praksis manusia. Terakhir, adanya delegasi (delegation) atau yang sering dijelaskan sebagai 'penulisan skrip dan intensionalitas yang disengaja' serta multistabilitas yaitu ketergantungan konteks pada skrip dan intensionalitasnya.

Mediasi teknologis tidak hanya dapat disederhanakan ketika teknologi mampu memediasikan antara manusia dan dunianya. Namun, konsepsi sumber mediasi menyaratkan adanya kompleksitas jaringan yang saling terkait dan saling terbangun satu dengan lainnya. Pada tataran pengguna subjek memiliki dimensi 
interpretatif untuk memahami teknologi secara kontekstual. Desainer membantu mendelegasikan nilai-nilai yang dibentuk oleh masyarakat. Desain yang terbentuk akan selalu relevan dengan teknologi yang dikembangkan. Teknologi itu sendiri muncul dari kompleksitas relasional baik dari segi sosial maupun alam.

Setelah teknologi hadir di tengah-tengah kondisi masyarakat, setiap orang dapat mengondisikan teknologi begitu pula teknologi memediasikan segala nilai-nilai yang telah dibawanya. Teknologi bukan finalitas sebab masih selalu bergerak pada progresivitas tertentu. Dari teknologi yang ada sekarang akan selalu membantu pengembangan teknologi berikutnya. Begitu juga bagaimana subjek sebagai aktor ada dan mengada. Penjelasan lebih lanjut tentang jejaring teknologi dan manusia akan dijelaskan secara spesifik oleh Bruno Latour melalui Actor Network Theory.

Teori Jaringan-Aktor menyediakan sebuah kerangka kerja konseptual untuk membahas struktur, tatanan dan interaksi sosial; kuasa dan sistem teknologis; serta infrastruktur teknis dan mesin dengan berpegang pada prinsip simetri umum. Serangkaian translasi dalam konfigurasi relasi-relasi menjadi kerangka kerja bahwa suatu entitas teknis sebagai kemenjadian in-the-becoming. Teori jaringan-aktor menjelaskan tentang konsep bagaimana realitas dalam kemenjadiannya, dalam gerak untuk menjadi dan bukan sebagai gerak yang tetap (Yuliar, 2009).

Manusia sebagai agen memiliki dimensi motivasi, kehendak, dan mampu menghasilkan pengetahuan. Kehadiran manusia tidak dapat direduksi pada dominasi kekuatan struktur sosial. Sumber utama dari aksi-aksi volunter berasal dari kehendak dan pengetahuan manusia. Dimensi-dimensi inilah yang memberikan manusia peluang mengembangkan teknologi. Manusia dalam aksinya tidak hanya berdiri secara independen tetapi juga terlibat dengan konteks sosialnya melalui proses pendelegasian dan distribusi kompetensi di antara unsur-unsur yang heterogen. Teori Jaringan Aktor merupakan translasi dan skrip di mana selalu beriringan dengan gerak entitas-entitas. Translasi karakteristik gerak dengan memperhatikan perubahan suatu entitas secara 
timbal balik dan relasional terhadap relasi lainnya. Skrip sebagaimana telah di jelaskan sebelumnya merupakan gagasan yang menjadi penghubungan antara aspek-aspek internal (kehendak dan pengetahuan manusia maupun sifat natural bendabenda) dengan transformasi dan translasi yang teramati di wilayah eksternal. Skrip itu sendiri mengalami encoding dan incsribing ke dalam serangkaian translasi. Translasi merupakan proses objektivikasi skrip (Yuliar, 2009).

Pandangan teori jaringan-aktor Latour tidak berbeda jauh dengan pemikiran mediasi teknologis Don Ihde terutama perihal penolakan distingsi antara subjek dan objek. Latour menawarkan konsep intinya tentang kesetaraan atau simetri yang terjalin antar subjek dan objek. Latour mengandaikan bahwa antara agen dan teknologi selalu saling berhubungan dengan konteks sosialnya. Artinya, teknologi tidak dapat berdiri sendiri dan netral begitu pula dengan agen tidak dapat sepenuhnya independen ketika melakukan aksi. Terlebih hari ini kita hidup di tengah-tengah teknologi yang tersituasikan dengan keseharian manusia (Rosenberger \& Verbeek, 2015).

Pandangan realisme spekulatif diterapkan oleh Graham Harman untuk menganalisis lebih lanjut tentang alat atau tools. Pandangan Harman tentang alat atau teknologi dapat diterapkan untuk menganalisis bagaimana corak mediasi teknologis. Tool Being bagi Harman menjadi pembahasan yang paling penting sepanjang sejarah metafisika teknologi. Harman menarik diri pada pembahasan tentang pemaknaan kembali alat/instrumen secara ontologis. Bagi Harman persoalan pembahasan teknologi selama selalu terjebak hanya pada tataran empiris tanpa mengarahkan pada hakikat dari teknologi itu sendiri.

Harman mengutip banyak pandangan Heidegger mengenai teknologi terutama tentang konsep present-at-hand (vorhandenheit) atau eksistensi objek/alat dan ready-to-hand (zuhandenheit) atau esensi objek/alat. Selama ini pemahaman akan esensi alat selalu berhenti pada istilah ready-to-hand atau ketika manusia menggunakannya, padahal sesungguhnya itulah momen ketika alat 
hanya memanifestasikan kemampuan 'efek'-nya yang secara parsial. Meskipun demikian, Harman tetap mengkritik Heidegger yang hanya berhenti pada pandangan bahwa alat telah selesai pada tahap present-at-hand sebagai objek fisik meskipun alat itu sendiri telah melampaui tahapan tersebut (Harman, 2011).

Pembacaan teknologi secara metafisik selalu luput sebab manusia hanya berhenti pada tataran basis visual. Pemahaman yang tidak sempurna hanya memahami apa yang tercerap tanpa mengkritisi penyebabannya. Persoalan kausalitas faktor sekunder teknologi sering kali diabaikan. Oleh karena itu, perlu adanya asumsi ontologis yang lebih kompeten untuk menjelaskan momen keterabaian tersebut. Harman menyebutnya sebagai sebuah invisible realms, di maka struktur kehidupan kita saat ini telah ada dan terbentuk tanpa manusia sadari sepenuhnya.

Teknologi sejatinya selalu menyembunyikan akan dirinya sendiri tanpa perlu adanya peranan manusia. Konsepsi ready-athand inilah yang selalu memberikan efek tertentu sehingga membuai kesadaran seolah tidak dapat dipahami. Efek ilusif dalam manifestasi kehadirannya ini sebagai totalitas yang terkadang membuat manusia melupakan bagian-bagian elemen dasar yang membangunnya. Misalnya ketika pengendara sepeda motor menggunakan motor, hanya yang hadir di hadapannya sebagaimana motor yang berfungsi untuk mengantarkannya namun seolah melupakan bahwa ada prinsip-prinsip yang bekerja dibaliknya secara simultan. Memahami alat berarti perlu memahami bagaimana jaringan teknologi terbentuk bukan lagi dalam artian yang mengisolasi atau membatasi akan alat itu sendiri (Harman, 2011).

Objek teknik dapat dikenali ketika manusia mampu melepaskan konstruksi pikirannya sendiri dan berusaha tidak selalu menilai realitas teknologi yang ada di luar secara subjektif. Objek akan selalu menghasilkan sesuatu yang bukan sebagaimana objek itu sendiri karena adanya daya tertentu yang akan mampu menghasilkan efek tertentu pula dalam realitas. Uniknya, efek-efek yang dihasilkan secara normal kemudian disebut sebagai sebuah 
fungsi. Fungsi dengan keterkaitan dengan objek-objek lainnya sesungguhnya tidak dapat diketahui secara penuh atau utuh dalam konteks riil-nya. Sifat fungsional teknologi selama ini memungkinkan untuk menyingkap misteri kehidupan tetapi faktanya selalu saja menyisakan hal-hal yang belum diketahui secara pasti pada tools tersebut dan akan secara terus menurus menciptakan ruang 'misteri' tersebut.

Harman dalam (Rachman, 2013) lantas menawarkan konsep equipment untuk membangun lebih lanjut struktur realitas dengan basis objek dengan cara menunda subjek dan mengandaikan bahwa subjek sesungguhnya berada dalam realitas yang terus berubahubah. Totalitas teknologi ini menjadikan realitas selalu bergerak dan berubah seiring kemampuan efek yang diproduksinya dan saling terkait dengan manusia di dalamnya. Pemahaman manusia akan alat pada akhirnya tidak akan pernah mencapai final sebab alat selalu berubah dan berkembang sejalan dengan fungsi-fungsi baru yang muncul.

Meskipun demikian, ada hal yang lebih menarik bahwa penarikan suatu objek tidak diderivasi secara ketat menjadi hubungan subjek-objek, tetapi juga dapat ditemukan sebagaimana dalam hubungan objek-objek. Artinya, teknologi juga memiliki relasinya dengan teknologi yang lain. Objek bertemu objek sebagaimana ketika manusia dengan manusia dalam konteks sosialisasinya. Teknologi tidak berakhir atau menjadi ketika difungsikan atau digunakan oleh manusia (Harman, 2010). Interaksi antara palu dan paku sejatinya tidak berbeda jauh dengan interaksi antara manusia dan palu ketika dipegang atau digunakan, yang membedakan keduanya hanya pada tingkatan atau derajatnya. Relasi palu tidak lagi mengurusi hal-hal yang dibingkai secara fisik oleh manusia dan terkadang tidak lagi relevan pada tataran relasinya misalnya warna atau bau dari paku itu sendiri, teknologi 'menarik diri' dari relasinya.

Fakta bahwa objek yang sama memiliki interaksi yang berbeda hanya pada kualitasnya yang relevan maka interaksi secara spesifik dapat terjadi. Objek-objek sangat memungkinkan untuk saling 
'menyapa' atau bertemu meskipun berbeda. Misalnya, sehelai daun yang bertemu dengan dinding yang keras. Sentuhan tidak menguras realitas antar keduanya, juga tidak mereduksi satu sama lainnya (Harman, 2010). Dengan demikian, objek dapat dilihat sebagai sebuah rantai interaksi dengan objek lainnya dengan cara yang sama sebagaimana manusia ketika berinteraksi dengan objek. Objek maka dapat berbicara secara tidak langsung melalui relasinya dengan objek-objek lainnya terlebih lagi ketika bersentuhan dengan subjek-manusia.

Corak mediasi teknologis bersifat tersembunyi dan tidak secara eksplisit sebagaimana para pemikir di bidang filsafat teknologi karena pemikiran Harman hanya terletak pada realisme spekulatif. Teknologi tidak dapat dipandang secara sederhana terlebih lagi mereduksinya secara naif. Harman lebih setuju jika teknologi diarahkan secara radikal sebagaimana sebuah being yang memiliki konsepsi metafisik dan menciptakan sistemnya sendiri.

Antisipasi pesimisme diatasi oleh Simondon melalui $\mathrm{Du}$ mode d'existence des objets techniques, yang berpendapat bahwa relasi universal antara budaya dan teknologi berada di luar fase yang stabil, fase ini tidak hanya mengalienasi hubungan manusia dengan teknik, tetapi juga ke kondisi simultan 'perbudakan teknologi'. Meskipun perkembangan teknologi terjadi melalui pengungkapan dan pemanfaatan progresif, kondisi ini sudah berlangsung sejak lama dan terkesan sangat tumpang tindih satu dengan yang lainnya. Simondon menawarkan bentuk pemikiran filosofisnya melalui refleksi sebagai "bentuk sadar dari resonansi internal yang dibentuk oleh manusia dan konkretisasi objektif", sehingga dapat mencegah alienasi antara manusia dan teknologi dengan memastikan bahwa kemajuan teknologi menjadi "bagian integral dari kemajuan manusia, dengan membentuk sistem dengan manusia" (Simondon, 2010)

Pemikiran khas dari Simondon yang membangun corak mediasi teknologi dengan strategi yang digunakan untuk merujuk hubungan antara teknologi, kebudayaan, dan manusia itu sendiri. Ketiga entitas ini saling berkaitan. Pertama, pemikiran Simondon 
mengizinkan untuk berpikir secara terbuka bahwa teknologi melampaui konstruksi sosial (Massumi et al., 2009). Teknologi berkembang bukan sekedar inovasi melainkan melampaui dimensi tersebut. Individuasi menjadi titik pijaknya sebab selalu pada waktu yang bersamaan bersifat psikis, kolektif, dan teknis (Stiegler \& Lebedeva, 2009).

Kedua, Simondon mempertanyakan ulang serangkaian pertanyaan di sekitar persoalan subjektivitas dan identitas. Simondon menantang konsep yang sudah mapan terkait pandangan teknologi secara tradisional. Teknologi tidak hanya membentuk subjektivitas atau identitas tetapi justru menjadikannya sebagai proses individuasi. Filsafat individuasi Simondon dalam (Chabot, 2013) menempatkan di mana teknologi, subjektivitas dan struktur adalah proses yang tak terpisahkan. Eksistensi tidak dimulai dari individu, namun dapat saja terjadi pra-individu. Alasan inilah yang membuka peluang lebih lanjut mempertanyakan kembali corak mediasi pada teknologi itu sendiri.

Simondon melihat sifat reflektif pada teknologi itu sendiri dapat sebagai sumber dari progresivitas yang dinamis. Teknologi bukan sekedar materialisasi dari potensi manusia melainkan juga mengombinasikan segala hal termasuk kreativitas manusia itu sendiri. Kata kunci untuk memahami filsafat teknologi Simondon setidaknya akan selalu bertalian dengan beberapa istilah antara lain: individuasi manusia maupun individuasi teknologi, proses kritis dan kreatif, kreativitas dari pra-individu dan pra-organisasi, struktur, represi, pembaruan, dan inovasi serta temuan baru. Konteks inilah yang menekankan bahwa pandangan Simondon terhadap mediasi sangatlah terbuka sebagaimana gagasan Ihde maupun Latour.

Paul Dumouchel (1992) mendukung konsepsi Simondon tentang kesalahan terbesar pemahaman manusia akan esensi teknologi. Teknologi tidak dapat direduksi hanya pada tataran penggunaan atau praktis. Ketika manusia melakukan reduksi atas teknologi maka realitas teknologi akan semakin menjauh dari subjek. Penulis menyatakan bahwa mediasi teknologis akhirnya 
tidak dapat dipahami secara penuh. Simondon lantas memberikan alternatif pandangan bahwa untuk memahami makna teknologi secara benar dan tepat harus menilik kembali relasi dan mediasi teknologi secara intensional. Objek teknis harus dilihat dan dipahami sebagai kualitas historis tetapi memiliki sifat intrinsik yang terletak pada proses yang sedang berlangsung. Catatan paling penting ialah membuka kembali sejauh mana dimensi reflektif dan kritis manusia untuk melawan rezim teknologi yang bersifat negatif dan pesimis. Kegagalan memahami teknologi artinya bagi Simondon juga secara tidak langsung merupakan kegagalan akan refleksi.

Mediasi teknologis ala Simondon salah satunya terwujud pada gagasannya tentang relasi antara lingkungan dan teknologi. Permasalahan lingkungan saat ini tidak serta merta menyalahkan begitu saja teknologi yang ada saat ini. Misalnya pencemaran lingkungan maka tidak dapat lantas secara sederhana dan reduktif hanya menekankan pada kesalahan desain dari teknologi itu sendiri. Novaes de Andrade (2008) secara eksplisit menyatakan bahwa teknologi harus diselamatkan dari 'perbudakan teknologis'. Lingkungan dan teknologi diharuskan memiliki titik temu yang simetris karena baik teknologi dan lingkungan sifatnya saling memilik pengaruh. Namun, teknologi justru menjadi mesin penghancur terutama saat konteks teknologi dikuasai atas kendali prinsip pasar kapital. Simondon mempertegas bahwa manusia harus dapat menyelamatkan teknologi dari sistem kapitalisme sebagai syarat yang diperlukan untuk mencapai lingkungan lebih baik.

Dari hasil deskripsi di atas, penulis menarik satu poin corak mediasi teknologi dalam perspektif Simondon. Teknologi melebihi konteks utilitasnya, teknologi lantas tidak hanya menjadi barang siap pakai dan selesai pada ranah praktis. Teknologi menemukan dan menghasilkan hubungan baru antara manusia dan nonmanusia, manusia dan benda, atau antara manusia dan manusia, atau antara teknologi dan teknologi. Teknologi merupakan jaringan 
terhubung. Jauh dari menandai keterasingan manusia dari dunia alami, teknologi merupakan perantara antara manusia dan alam.

Teori kritis teknologi yang dikembangkan oleh Andrew Feenberg agaknya memberikan gambaran yang berbeda dengan pendahulunya Marcuse. Teknologi diarahkan agar dapat meningkatkan kualitas kehidupan manusia di segala bidang, bukan hanya materi tetapi juga mengatasi persoalan alienasi manusia. Manusia menjadi dirinya sendiri atau subjek itu sendiri. Semuanya dapat terwujud jika kontrol demokratis juga diarahkan pada pengembangan dan penggunaan teknologi (Feenberg, 2002). Salah satu gagasannya ialah terkait demokratisasi teknologi (Feenberg, 2012). Demokratisasi teknologi membuka ruang dialog teknis secara kritis, yang menjelaskan bahwa teknologi selalu memediasi dunia dan manusia walaupun memiliki struktur yang berbeda namun mediasi tidak serta merta menjadikan demarkasi naif. Baik masyarakat, teknologi, dan dunia ketiganya bergerak bersama. Kode teknis adalah kunci utama bahwa setiap teknologi terkonstruksi untuk mentranformasi sesuatu hal. Bagi Feenberg mediasi teknologis dapat dijamin sejauh teknologi bersifat transformatif dan emansipatoris di tengah-tengah masyarakat.

Konsepsi mediasi teknologi harus memiliki latar belakang ontologi secara eksplisit. Penulis menjelaskan secara singkat bahwa dimensi ontologis artefak teknis mampu menjelaskan asal muasal teknologi dan menyelesaikan persoalan distingsi antara subjek dan objek yang naif. Mediasi teknologis pada artefak teknis hadir secara terus menerus tanpa adanya keterputusan karena pada dasarnya artefak teknis memiliki dasar ontologis yang melibatkan dwi-esensi atau dual nature di mana tidak melepaskan mana ranah alamiah material dan mana ranah sosial, sebab keduanya sama-sama memiliki kontribusi secara berkelanjutan pada proses mediasi teknologis itu sendiri. 


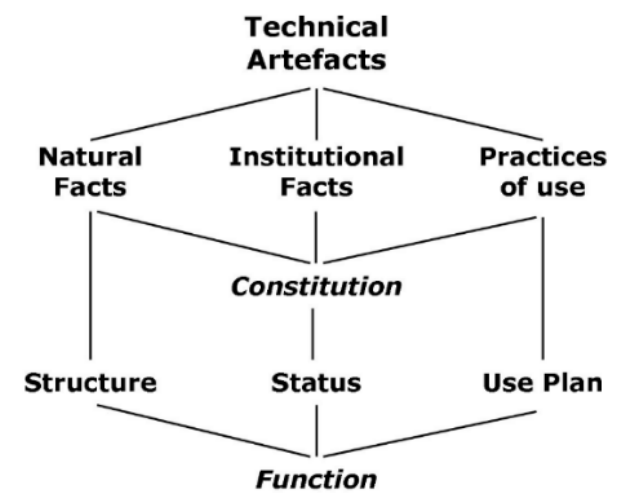

Gambar 3. Konsep Ontologi Artefak

Menurut Pasi Pohjola pendekatan ontologis pada artefak sangat bermakna positif karena mampu mengelaborasikan tradisi (materialis) ontologi dan ontologi sosial. Adanya tindakan sebagai praksis artefak serta konteks sosial yang ikut serta mengonstitusikan properti material sehingga menjadikannya memiliki status ontologi (artefak). Pada gambar konsep ontologi artefak terlihat adanya 'hierarki' secara konseptual yang melatarbelakangi struktur ontologis terbentuknya artefak teknis. Seluruh entitas yang ada pada konsep di atas saling berpengaruh satu sama lainnya. Misalnya, artefak teknis mengada karena adanya fakta alamiah (material), fakta institusional, dan fakta penggunaan teknis (Pohjola, 2007). Oleh sebab itu, masing-masing dari fakta tersebut memiliki latar belakang atau bahkan kelanjutan pada ranah domain yang berbeda-beda baik dari segi struktur, status, maupun kegunaan yang semuanya akan mengarah pada fungsi dari teknologi itu sendiri

Diskursus ontologi artefak yang pertama ialah tentang sifat ganda artefak atau dwi-esensi atau dual nature yang selalu melibatkan fakta-fakta yang mendasarinya. Artefak pada dasarnya merupakan konstitutif dari dua jenis fakta: fakta alam dan institusional atau kelembagaan. Fakta alam keberadaannya tidak tergantung pada keterlibatan manusia, merujuk pada struktur fisik dan sifat artefak. Sedangkan fakta kelembagaan tergantung pada 
keterlibatan manusia, merujuk pada status artefak. Status artefak ini juga terkait dengan penggunaannya. Artefak sangat bergantung pada fitur konstitutif yang berpijak pada fakta institusional dan cakupannya lebih luas dari pada hanya sekedar fakta sosial umum. Mengapa demikian? Karena fakta-fakta institusional sangat bergantung pada penerimaan kolektif, sedangkan fakta sosial dapat bergantung pada kepercayaan dari segelintir agen sehingga fakta kelembagaan memiliki kontribusi yang sangat signifikan terhadap ontologi artefak (Kroes, 2010).

Landasan ontologi holistik pada artefak dapat memberikan landasan bahwa teknologi juga menyinggung sebagaimana diskursus pada mereologi perihal bagian (part) dan keseluruhan (whole). Artinya, untuk memahami secara mendalam bagaimana mediasi teknologis bekerja pada artefak teknis diperlukan komitmen secara ontologi bersifat holistik. Alasannya bahwa teknologi tidak dapat dijustifikasi hanya pada bagian-bagian tertentunya atau keseluruhannya. Bagaimana kita bisa menjelaskan teknologi komputer tanpa merujuk pada sistem perangkat lunak yang bekerja di belakang secara kasat mata ataupun sebaliknya. Oleh karena itu, corak mediasi teknologis dapat ditemukan pada konsep artefak teknis bahwa apa yang bersifat material-alamiah tidak serta merta terlepas independen begitu saja dengan komitmen atau keputusan kolektif di ranah kelembagaan sosial. Artefak selalu membawa dua sifat dimensi alam dan sosial. Artefak teknis bukan sesuatu yang pasif tergeletak. Fungsi dari teknologi secara instrumentasi juga memerlukan proses dan uniknya tidak lagi menjadi sebuah finalitasnya.

\section{SIMPULAN}

Metafisika mediasi teknologis bukan konsep final dalam diskursus filsafat teknologi tetapi pada penelitian ini mengawali untuk memetakan ulang bahwa filsafat teknologi sudah berkembang secara signifikan. Filsafat teknologi klasik terjebak pada penalaran filosofis yang bersifat deterministik dan pesimistik akan eksistensi teknologi yang seolah mendominasi kehidupan 
manusia. Penulis memberikan tiga tipe filsafat teknologi klasik yang terbagi berorientasi pada pandangan deterministik, dominasi, dan netralitas. Lantas, pada tipe keempat atau mediasi teknologis dapat memberikan rekonstruksi pemahaman ontologi relasional tentang subjek-objek teknologis.

Beberapa pandangan filsafat teknologi yang telah berkontribusi membangun landasan metafisika mediasi teknologis antara lain: posfenomenologi dengan konsep ontologi relasional dan intensionalitasnya, teori jaringan aktor melalui konsep simetri umum, individuasi Simondon, orientasi objek Harman, kritik teknologi Feenberg, dan pandangan ontologi holistik dalam dwiesensi atas artefak teknis. Teknologi pada konsepsi pemikir kontemporer tidak lagi terjebak pada 'pemaksaan' orientasi hasil yang sifatnya general-spekulatif tetapi lebih pada meneliti secara parsial dan bertahap.

\section{DAFTAR PUSTAKA}

Achterhuis, H. (2001). American philosophy of technology: The empirical turn. Indiana University Press.

Boever, D. (2012). Gilbert Simondon: Being and Technology. Edinburgh University Press.

Brey, P. (2010). Philosophy of technology after the empirical turn. Techné: Research in Philosophy and Technology, 14(1), 36-48.

Chabot, P. (2013). The philosophy of Simondon: Between technology and individuation. A\&C Black.

Dumouchel, P. (1992). Gilbert Simondon's plea for a philosophy of technology. Inquiry, 35(3-4), 407-421.

Feenberg, A. (2002). Transforming technology: A critical theory revisited. Oxford University Press.

Feenberg, A. (2012). Questioning technology. Routledge.

Franssen, M., Vermaas, P. E., Kroes, P., \& Meijers, A. W. M. (2016). Philosophy of technology after the empirical turn. Springer. 
Harman, G. (2010). Prince of networks: Bruno Latour and metaphysics. re. press.

Harman, G. (2011). Tool-being: Heidegger and the metaphysics of objects. Open Court.

Heidegger, M. (1977). The question concerning technology. Harper \& Row New York.

Ihde, D. (1979). Technic and Praxis. Dordrecht Reidel Publishing Company.

Ihde, D. (2009). Postphenomenology and technoscience: The Peking university lectures. Suny Press.

Jonas, H. (2014). Technology and responsibility: reflections on the new tasks of ethics. In Ethics and emerging technologies (pp. 3747). Springer.

Kapp, E. (2018). Elements of a philosophy of technology: on the evolutionary history of culture. U of Minnesota Press.

Kiran, A. H., \& Verbeek, P.-P. (2010). Trusting our selves to technology. Knowledge, Technology \& Policy, 23(3-4), 409-427.

Kroes, P. (2010). Engineering and the dual nature of technical artefacts. Cambridge Journal of Economics, 34(1), 51-62.

Latour, B. (2005). Reassembling the Social: An Introduction to ActorNetwork-Theory. OUP Oxford.

Lim, F. (2008). Filsafat Teknologi, Don Ihde Ttg Manusia \& Alat. Kanisius.

MacBride, F. (2016). Relations. SEP Online.

Mahaswa, R. K. (2018). Terrestrial Turn: Diskursus Antroposen dalam Filsafat Teknologi. Universitas Gadjah Mada.

Massumi, B., De Boever, A., Murray, A., \& Roffe, J. (2009). Technical Mentality" revisited: Brian Massumi on Gilbert Simondon. Parrhesia, 7(1), 36-45. 
Negoro, S. T., \& Harahap, B. (2010). Ensiklopedia matematika. Ghalia Indonesia.

Novaes de Andrade, T. (2008). Technology and environment: Gilbert Simondon's contributions. Environmental Sciences, 5(1), 7-15.

Pohjola, P. (2007). Technical artefacts: an ontological investigation of technology (Issue 300). University of Jyväskylä.

Rachman, A. (2013). Kritik Realisme Spekulatif terhadap Penggunaan Teknologi di era Kontemporer. Universitas Indonesia.

Rosenberger, R., \& Verbeek, P.-P. (2015). A field guide to postphenomenology. Postphenomenological Investigations: Essays on Human-Technology Relations, 9-41.

Simondon, G. (2003). An Introduction to Science and Technology Studies. Wiley-Blackwell.

Simondon, G. (2010). The limits of human progress: A critical study. Cultural Politics, 6(2), 229-236.

Stiegler, B., \& Lebedeva, K. (2009). The theater of individuation: Phase shift and resolution in Simondon and Heidegger. Parrhesia, 7, 46-57.

Thomson, I. (2000). From the question concerning technology to the quest for a democratic technology: Heidegger, Marcuse, Feenberg. Inquiry, 43(2), 203-215.

Verbeek, P.-P. (2006). Materializing morality: Design ethics and technological mediation. Science, Technology, \& Human Values, 31(3), 361-380.

Verbeek, P.-P. (2008). Cyborg intentionality: Rethinking the phenomenology of human-technology relations. Phenomenology and the Cognitive Sciences, 7(3), 387-395.

Verbeek, P.-P. (2012). Expanding mediation theory. Foundations of Science, 17(4), 391-395. 
Verbeek, P.-P. (2015a). Beyond interaction: a short introduction to mediation theory. Interactions, 22(3), 26-31.

Veerbek, P.-P. (2015b). Toward a Theory of Technological Mediation: a Program for Postphenomenological Research. Technoscience and Postphenomenology: The Manhattan Papers, 189204.

Vieta, M. (2010). Hope for our technological inheritance? From substantive critiques of technology to Marcuse's posttechnological rationality. Strategies of Critique.

Yuliar, S. (2009). Tata kelola teknologi: Pengantar teori jaringan-aktor. Penerbit ITB.

Zwier, J., Blok, V., \& Lemmens, P. (2016). Phenomenology and the empirical turn: A phenomenological analysis of postphenomenology. Philosophy E Technology, 29(4), 313-333. 